\title{
PENGEMBANGAN MEDIA PEMBELAJARAN AUGMENTED REALITY (AR) DI KELAS V MI WAHID HASYIM
}

\author{
Fajar Dwi Mukti \\ Dosen STPI Bina Insan Mulia Yogyakarta \\ Email: Fajardwimukti@gmail.com
}

\begin{abstract}
This development research aims to find out the results of the response of teachers and students so that decent media used in learning. The development model used in this medium is the modified Thiagarajan $4 D$ model. The stages carried out consist of three stages, namely Define, Design, and Development. The media for learning Augmented Reality (AR) was assessed by 1 media expert, 1 matter expert, 1 peer reviewer, 1 class $V$ teacher and $10 \mathrm{~V}$ grade students MI Wahid Hasyim to find out student responses. The instruments used were questionnaire and evaluation sheets using non-objective description forms for testing the quality of learning media products. The results of the study are response or response of class $V$ teachers is very good with a percentage of $82.57 \%$. Likewise, the students' responses obtained a percentage of $90.2 \%$ with a positive response so that the learning media had a quality category on the Very Good criteria which was also supported by the results of students who experienced an increase of $35.8 \%$. Based on the results of data acquisition shows that the learning media of Augmented Reality (AR) in class V MI Wahid Hasyim is worthy of being used as a learning resource for students.
\end{abstract}

Keywords: Development Research, Learning Media, Augmented Reality 


\begin{abstract}
Abstrak
Penelitian pengembangan ini bertujuan untuk mengetahui hasil respon guru dan siswa sehingga media layak digunakan dalam pembelajaran. Model pengembangan yang digunakan dalam media ini adalah model 4D Thiagarajan yang telah dimodifikasi. Tahapan yang dilakukan terdiri dari tiga tahap yaitu Define (pendefinisian), Design (perancangan), dan Develop (pengembangan). Media pembelajaran Augmented Reality (AR) ini dinilai oleh 1 orang ahli media, 1 orang ahli materi, 1 orang peer reviewer, 1 orang guru kelas $\mathrm{V}$ dan 10 siswa kelas V MI Wahid Hasyim untuk mengetahui tanggapan siswa. Instrumen yang digunakan adalah lembar angket dan evaluasi menggunakan bentuk uraian non objektif untuk uji kualitas produk media pembelajaran. Hasil penelitian adalah respon atau tanggapan guru kelas V Sangat Baik dengan diperoleh persentase $82.57 \%$. Begitu juga tanggapan siswa diperoleh persentase $90.2 \%$ dengan tanggapan positif sehingga media pembelajaran memiliki kategori kualitas pada kriteria Sangat Baik yang didukung juga dengan hasil nilai siswa yang mengalami penaikan 35.8\%. Berdasarkan hasil perolehan data menunjukkan bahwa media pembelajaran Augmented Reality (AR) di kelas V MI Wahid Hasyim layak dipergunakan sebagai sumber belajar siswa.
\end{abstract}

Kata Kunci: Penelitian Pengembangan, Media Pembelajaran, Augmented Reality

\title{
A. Pendahuluan
}

Di era 4.0 ini menuntut kita untuk melakukan aktivitas dengan seefektif mungkin sehingga peran teknologi sangat dibutuhkan sebagai salah satu penunjang aktivitas terutama dibidang pendidikan. Indonesia dilihat dari perkembangan teknologi di dunia menurut lembaga Internasional Telecommunication Union (ITU) dalam penetapan ranking ICT Development Indeks (IDI) mendapat peringkat 108 dari 167 negara di dunia (Sanou Brahima, 2015:11). Sedangkan berdasarkan riset Kementrian Komunikasi dan Informatika Republik Indonesia dan UNESCO tahun 2014, sebanayak 30 juta anak-anak dan remaja di Indonesia adalah pengguna internet, dan media digital saat ini menjadi pilihan yang utama untuk komunikasi. 
Hasil studi menunjukkan bahwa 80 persen responden yang diteliti adalah pengguna internet, dengan penemuan yang telah dibuktikan kesenjangan digital yang kuat antara mereka yang bertempat tinggal di wilayah perkotaan, dengan mereka yang di daerah perdesaan. Di Daerah Istimewa Yogyakarta, Jakarta dan Banten, misalnya, ratarata semua responden merupakan pengguna internet. Sementara di Maluku Utara dan Papua Barat, kurang dari sepertiga hasil penemuan jumlah responden telah menggunakan internet (Gatot S. Dewa Broto, 2017).

Sejalan perkembangan teknologi informasi, lembaga pendidikan mulai gencar melakukan inovasi terhadap kegiatan belajar mengajar. Suatu inovasi baru sangat dibutuhkan dalam dunia pendidikan karena dengan adanya inovasi baru tersebut kualitas pendidikan dapat ditingkatkan. Kegiatan belajar mengajar di setiap satuan pendidikan diharapkan mengarah pada basis teknologi (Gatot S. Dewa Broto, 2017). Augmented Reality merupakan sistem yang unik di bidang teknologi informasi. Augmented Reality (AR) adalah sintesis perumpamaan nyata dan virtual (Atmajaya dan Dedy, 2017:228). Aplikasi Augmented Reality sudah diterapkan di berbagai bidang, dimana Augmented Reality dijadikan sebagai konsep aplikasi yang dipergunakan untuk menggabungkan dunia fisik (objek sesungguhnya) dengan dunia digital, tanpa mengubah bentuk objek realitasnya. Pengenalan objek (teks dan gambar) dipergunakan sebagai alat untuk menampilkan informasi. Sehingga Augmented reality dikatakan sebagai sistem kognitif yang mampu memahami secara utuh persepsi dari pengguna (Boud, A. C dan Haniff, D. J., 1999:4).

MI Wahid Hasyim adalah salah satu sekolah dasar yang berada di Yogyakarta wilayah Kabupaten Sleman. Sekolah MI Wahid Hasyim memiliki sistem pembelajaran menggunakan media pembelajaran buku atau gambar-gambar $2 D$ dan video. Hal ini tentu membuat siswa menjadi mudah bosan dan bahkan dalam memahami pembelajaran akan mengalami kesulitan. Maka dari itu sistem atau cara baru dalam pembelajaran siswa di madrasah ibtidaiyah perlu diperhatikan, Karena siswa MI masih tergolong usia anak-anak yang selalu menyukai hal yang berbeda dan baru. Saat 
ini di MI Wahid Hasyim sudah menggunakan alat-alat peraga untuk mengajar siswanya seperti gambar 2D dan video namun bukan tidak mungkin diperkenalkan teknologi lain sebagai sarana pembelajaran untuk siswa. Sistem pembelajaran interaktif yang memanfaatkan teknologi media pembelajaran Augmented Reality (AR) belum pernah dipergunakan di MI Wahid Hasyim sehingga ini merupakan hal baru bagi siswa MI Wahid Hasyim. Walaupun sudah menggunakan media pembelajaran tetapi media pembelajaran seperti gambar gambar 2D kurang sesuai dengan kriteria media pembelajaran yang baik, media pembeljaran yang baik menurut Kustandi, C.,Sutjupto, B., Asnawir (2013:80-81) dan Usman, B., (2002:126) hasil komparasi kedua buku tersebut maka disimpulkan sebagai berikut: praktis, luwes, ketahanan, Efektifitas dan Efisien. Berdasarkan pendapat tersebut diketahui gambar 2D dari segi keluwesan masih kurang karena hanya bisa melihat dari satu sisi dan siswa tidak bisa berinteraksi dengan gambar dll.

Sedangkan pada media pembelajaran Augmented Reality (AR) yang berbasis teknologi yang tersimpan pada file .apk, dari segi keluwesan bagus karena siswa mampu berinteraksi dan mampu melihat objek 3D yang mampu di perbesar, di perkecil dan bahkan di putar untuk menyesuaikan kebutuhan yang ada. Tidak hanya itu, media pembelajaran yang dirancang mampu menampilkan turunnya hujan dan penguapan secara real time dan masih banyak lagi kelebihan yang dimiliki media pembelajaran Augmented Reality (AR) ini. Jika dilihat dari segi praktis, media pembelajaran Augmented Reality (AR) lebih praktis karena mudah dibawa kemana - mana dan melihat objek 3D, dimana dalam teknologi yang dirancang mampu memberikan layanan terhadap pendidik yang kurang suka akan membaca dan siswa yang memiliki karakter aktif. Kemudian dari segi pembelajaran gambar 2D mengakibatkan siswa mudah bosan sehingga kurangnya konsentrasi dan mengakibatkan sulitnya memahami materi daur air.

Sehingga penelitian media pembelajaran Augmented Reality (AR) yag dirancang sangat penting, karena pembelajaran dengan menampilkan objek $3 D$ dan animasi melalui pemanfaatan teknologi 
yang tengah dikembangkan diharapkan siswa mampu memahami materi dengan baik, salah satunya dengan menggunakan teknologi media pembelajaran Augmented Reality (AR). Teknologi ini mungkin bagi beberapa orang masih terdengar asing tetapi juga sebagian orang sudah terbiasa melihat media pembelajaran tersebut, maka dalam perancangan media pembelajaran Augmented Reality (AR) menampilkan fiture baru yang unik dibandingkan dengan media yang telah ada.

Penerapan Augmented Reality (AR) meningkatkan pengalaman atas kolaborasi ruang nyata dan semu sebagai kontribusi untuk pendidikan. Melalu media pembelajaran Augmented Reality materi daur air, Augmented Reality (AR) meningkatkan proses pembelajaran dan memfasilitasi pemahaman penggunanya tentang konteks objek alam dan menghubungkan mereka ke tiap detail fisik gejala alam dan siklus yang mendukung, terutama apresiasi rincian sistem daur air dari awal sampai terjadinya hujan. Cara ini praktis meningkatkan pemahaman tentang daur air. Kebutuhan akan visualisasi dan interaksi yang biasa dilakukan di berbagai disiplin ilmu dapat dioptimalkan dengan menerapkan teknologi Augmented Reality (AR) yang sedang trend tersebut (Bahar, Y., N., 2014:37). Berdasarkan latar belakang tersebut maka peneliti berencana mengembangkan media pembelajaran dan mengetahui respon guru dan peserta didik terhadap media pembelajaran Augmented Reality (AR) di kelas V MI Wahid Hasyim.

\section{Metode Penelitian}

Penelitian ini merupakan penelitian dan pengembangan atau Research and Development (R\&D), yaitu penelitian yang digunakan dalam membuat produk tertentu, untuk menyempurnakan produk yang telah ada dan dilanjutkan dengan menguji keefektifan produk tersebut (Sugiyono, 2009:297). Adapun produk yang dikembangkan berupa Media Pembelajaran Augmented Reality (AR) untuk Siswa Kelas V MI Wahid Hasyim. Adapun model pengembangan berupa prosedural, yakni model yang bersifat deskriptif dan memiliki langkah-langkah yang harus diikuti dalam menghasilkan suatu 
produk (Tim Puslitjaknov, 2008:8). Prosedur pengembangan yang digunakan yakni mengikuti model 4-D (Define, Design, Develop, dan Disseminate), atau diadaptaasikan menjadi model 4-P, yaitu pendefinisian, perancangan, pengembangan, dan penyebaran (Trianto, 2013:189), akan tetapi tahap tersebut dibatasi hanya sampai tahap Develop pada uji coba terbatas.

\section{B. Pembahasan}

Pada bab pembahasan mengkaji tentang penelitian terkait, penelitian pengembangan, media pembelajaran, augmented reality, dan hasil penelitian media pembelajaran Augmented Reality (AR) di kelas V MI Wahid Hasyim yang dibahas sebagai berikut.

\section{Penelitian Terkait}

Berdasarkan penelitian Matt Dunleavy, Chris Dede and Rebecca Mitchell Mitchell tujuan dari penelitian ini untuk mendokumentasikan bagaimana guru dan siswa menggambarkan dan memahami caracara di mana berpartisipasi dalam simulasi augmented reality (AR) membantu atau menghambat pengajaran dan pembelajaran. Guru dan siswa melaporkan bahwa narasi yang dimediasi teknologi dan penyelesaian masalah interaktif, terletak, kolaboratif dari simulasi AR sangat menarik, terutama di antara siswa yang sebelumnya telah menyajikan tantangan perilaku dan akademis bagi para guru. Namun, sementara simulasi AR memberikan nilai tambah yang berpotensi transformatif, itu secara simultan menyajikan tantangan teknologi, manajerial, dan kognitif yang unik untuk mengajar dan belajar (Dunleavy, M., Dede, D., and Mitchell, R., 2009).

Perbedaannya yaitu Augmented Reality (AR) yang tidak hanya mampu menampilkan objek 3D tetapi juga mampu menampilkan Augmented Reality (AR) video playback, walaupun pada dasarnya hampir memiliki kesamaan dan fokus penelitian, berdasarkan penelitian tersebut diketahui mengambil objek sekolah menengah yaitu kelas 6, 7 dan 10, sedangkan dalam penelitian penulis fokus di kelas 5. kemudian matapelajaran yang dipergunkan juga berbeda, dalam penelitian tersebut matapelajaran yang dipergunakan yaitu matematika tetapi dalam penelitian penulis mengambil mata 
pelajaran IPA. Dari segi sajian produk yang dihasilkan dalam penelitian tersebut masih terbatas dari desain dan praktisnya. Berdasarkan penelitian tersebut menjelaskan bahwa media pembelajaran menggunakan AR nilai tambah transformatif yang potensial, secara bersamaan disajikan teknologi unik, manajerial, dan tantangan kognitif untuk pengajaran dan pembelajaran.

Sehingga dalam penelitian pengembangan Media Pembelajaran Augmented Reality (AR) untuk Siswa Kelas V MI Wahid Hasyim sangat penting, disamping produk yang dihasilkan mampu menghadirkan sebuah konsep yang mampu dilihat secara real dan memiliki teknologi Augmented Reality (AR) video playback yang tergolong unik, sehingga dapat memungkinkan memiliki hasil yang berbeda dengan penelitian diatas.

Rujianto Eko Saputro dan Dhanar Intan Surya Saputra mengemukakan bahwa penggunaan Augmented Reality yang mampu merealisasikan dunia virtual ke dunia nyata, mampu mengubah objek-objek tersebut menjadi objek 3D, maka metode pembelajaran tidaklah monoton dan anak-anak jadi terpacu untuk mengetahuinya lebih lanjut, seperti mengetahui nama organ dan keterangan dari masing-masing organ tersebut (Saputro, R.E. dan Surya, D.I., 2015).

Persamaan penelitian ini adalah pada media pembelajaran AR yang dipergunakan sebagai alat bantu pengajaran dan matapelajaran yang sama yaitu IPA. Sedangkan perbedaannya yaitu pada sistem media pembelajaran yang tengah dibuat memiliki teknologi Augmented Reality (AR) video playback dan pada fokus penelitian, berdasarkan penelitian tersebut diketahui mengambil objek sekolah menengah pertama, tetapi dalam penelitian ini di sekolah dasar. Walaupun mata pelajaran yang dipergunkan juga sama tetapi materi yang digunakan berbeda yaitu mengenal organ tubuh sedangkan dalam penelitian ini mengambil materi daur air.

Berdasarkan penelitian tersebut menjelaskan bahwa media pembelajaran menggunakan AR merangsang siswa untuk lebih aktif mencari tau, seperti mengetahui nama organ dan keterangan dari masing-masing organ tersebut. Sehingga dalam penelitian pengembangan Media Pembelajaran memiliki teknologi Augmented

Elementary Vol. 7 No. 2 Juli-Desember 2019 
Reality (AR) untuk Siswa Kelas V MI Wahid Hasyim sangat penting karena dalam konsepnya memiliki teknologi Augmented Reality (AR) memiliki kemampuan yang memungkinkan memiliki hasil yang berbeda dengan penelitian diatas.

Adam Arif Budiman menjelaskan bahwa Hampir 100 persen orang dewasa dan 60 persen anak-anak pernah mengalami penyakit gigi berlubang. Hal ini terjadi karena masyarakat kurang memahami masalah gigi berlubang, baik pencegahan maupun pengobatan sehingga dengan menggunakan Augmented Reality sebagai media edukasi gigi berlubang memudahkan masyarakat untuk memahami tentang penyakit gigi berlubang.

Pernyataan tersebut didukung dengan data hasil responden terhadap aplikasi yang dibuat, respondennya berjumlah 50 dengan umur yang bervariasi, dari hasil pertanyaan apakah aplikasi ini informatif menunjukan tidak informatif $0 \%, 4 \%$ kurang informatif, $42 \%$ informatif dan $54 \%$ sangat informatif, sedangkan dalam pertanyaan aplikasi ini membantu memahami tentang gigi berlubang menunjukan tidak membantu 0\%, kurang membantu 3\%, membantu 44\% dan sangat membantu 50\% (Budiman, A. A., 2017).

Persamaan penelitian ini adalah pada media yang digunakan yaitu menggunakan perangkan mobile yang dipergunakan sebagai alat bantu untuk menjelaskan sebuah konsep. Sedangkan perbedaannya dalam penerapan sistem dalam mobile yaitu augmented relity sedangkan pada penelitian ini tidak hanya menggunakan teknologi Augmented Reality (AR) tetapi memiliki teknologi Augmented Reality (AR) video playback kemudian dalam segi kajian tersebut yaitu fokus penelitian, kemudian mengambil objek masyarakat luas yang terdiri dari anak - anak dan orang dewasa sedangkan pada penelitian ini berfokus pada anak usia sekolah dasar. Berdasarkan penelitian tersebut menjelaskan bahwa media AR mampu memudahkan masyarakat untuk memahami tentang penyakit gigi berlubang. Sehingga dalam penelitian pengembangan Media Pembelajaran memiliki teknologi Augmented Reality (AR) Untuk Siswa Kelas V MI Wahid Hasyim sangat penting karena dalam konsepnya Augmented 
Reality memiliki kemampuan yang memungkinkan memiliki hasil yang berbeda dengan penelitian diatas.

Wellia Shinta Sari dkk. menjelaskan teknologi AR yang dikembangkan akan dipakai untuk membantu mengembangkan multimedia presentasi pembelajaran dalam mendukung proses belajar mengajar materi pengenalan pancaindra tingkat Sekolah Dasar sehingga mampu mambantu siswa untuk memahami struktur dan fungsi pancaindra pelajaran IPA tingkat Sekolah Dasar khususnya kelas 4. Aplikasi AR dikembangkan dengan metode problem based learning yang meliputi tahap analisis, perancangan, pengembangan, dan pengujian. Aplikasi AR ini menggunakan gambar animasi 3D yang didesain menggunakan Autodesk 3ds Max dan dibangun menggunakan pemrograman flash dengan library FLARToolkit, Papaervision3D, dan FLARGenerator (Sari, W. S., dkk., 2012.

Persamaan penelitian ini adalah pada media pembelajaran yang menggunakan mobile yang dipergunakan sebagai alat bantu pengajaran di sekolah, matapelajaran yang sama yaitu IPA dan subyek yang diteliti juga sama yaitu anak sekolah dasar. Kemudian perbedaannya yaitu obyek dalam penelitian ini mengambil kelas 5 sedangkan dalam penelitian tersebut mengambil kelas 4 dan materi yang digunakan berbeda yaitu pengenalan pancaindra sedangkan dalam penelitian ini mengambil Materi Daur Air. Pengembangan aplikasi multimedia presentasi pembelajaran pancaindra dengan teknologi $A R$ dapat dipergunakan oleh guru sebagai alat bantu pengajaran di kelas dan dapat membantu siswa lebih memahami pelajaran IPA khususnya struktur dan fungsi pancaindra manusia. Multimedia presentasi pembelajaran dengan teknologi $A R$ dapat diterapkan untuk menggantikan metode pembelajaran konvensional.

Nia Saurina menjelaskan Media pembelajaran untuk anak usia dini merupakan alat bantu yang digunakan untuk mengenalkan tema-tema sebagai bahan ajaran atau yang sering disebut dengan kurikulum untuk anak usia dini. Semakin banyak alat indra yang terlibat dalam proses belajar maka semakin besar anak akan mudah paham pada materi yang disampaikan oleh pengajar atau guru. pengembangan media pembelajaran yang digunakan untuk 
mengenalkan binatang menggunakan Augmented Reality (AR), sehingga anak dapat mengetahui lingkungan hidup dan makanan yang dibutuhkan oleh binatang yang diperkenalkan tersebut.

Penelitian ini mengajak anak-anak KBIT Wildani 2 Surabaya sebagai responden hasil uji coba aplikasi yang telah dibangun. Hasil uji coba menghasilkan persentase $93 \%$ anak dapat mengenali objek binatang dari lingkungan hidupnya, sebesar $100 \%$ menyatakan anak mampu mengulang ejaan nama dari hewan menggunakan Bahasa Indonesia yang diperagakan melalui augmented reality, sebesar 95\% anak dapat mengulang ejaan nama dari hewan dengan Bahasa Inggris yang diperagakan dengan augmented reality, sebesar 95\% anak dapat menyebutkan ciri-ciri binatang dengan memilih salah satu bagian tubuh dari bidanatang yag dipilih, dan sebesar 100\% menyatakan anak lebih tertarik menggunakan AR daripada menggunakan Alat Peraga Edukasi (APE) sebagai media pembelajaran (Saurina Nia, 2016).

Persamaan penelitian ini adalah pada media yang digunakan yaitu perangkat mobile yang dipergunakan sebagai alat bantu untuk menjelaskan sebuah konsep. Sedangkan perbedaannya dalam kajian tersebut yaitu fokus penelitian, dimana dalam penelitian tersebut mengambil objek anak usia dini sedangkan pada penelitian ini berfokus pada anak usia sekolah dasar. Berdasarkan penelitian tersebut menjelaskan bahwa media AR mampu memudahkan anak usia dini untuk mengetahui binatang. Sehingga dalam penelitian pengembangan Media Pembelajaran memiliki teknologi Augmented Reality (AR) untuk Siswa Kelas V MI Wahid Hasyim sangat penting, disamping produk yang dihasilkan mampu menghadirkan sebuah konsep yang mampu dilihat secara real dan memiliki teknologi Augmented Reality (AR) video playback sehingga dapat memungkinkan memiliki hasil yang berbeda dengan penelitian diatas.

Berdasarkan urain penelitian - penelitian terdahulu diatas maka media pembelajaran Augmented Reality (AR) masih perlu diteliti lebih lanjut dengan produk yang lebih efektif. Penelitian penelitian diatas relevan dengan penelitian ini karena hasil penelitian di atas dapat memberikan informasi dan gambaran kepada peneliti 
tentang produk yang dipergunakan dan cara dalam pembuatan serta menerapkannya sebagai media pembelajaran, sehingga hasil penelitian ini diharapkan dapat mengembangkan hasil-hasil penelitian yang terdahulu.

\section{Penelitian Pengembangan}

Pengembangan media pembelajaran Augmented Reality (AR) ini mengacu pada prosedur yang dikembangkan oleh Thiagarajan, dkk yang kemudian dimodifikasi, dalam pemilihan prosedur tersebut mempertimbangkan aspek kemudahan dan disesuai dengan kebutuhan yang dilakukan dalam penelitian. Prosedur pengembangan dapat dilihat pada Gambar 1 .

a. Tahapan Define (Pendefinisian)

Tahap define dimulai dengan kegiatan analisis berbagai aspek yang dibutuhkan dalam pengembangan media, diantaranya adalah:

1) Analisis awal-akhir yang bertujuan untuk mengedintifikasi permasalahan mendasar yang diperlukan dalam pengembangan media.

2) Analisis karakter siswa bertujuan untuk mengetahui sajauh mana pengetahuan dan pemanfaaatan teknologi khususnya handphone dalam pembelajaran.

3) Analisis kurikulum dilakukan untuk mengidentifikasi Kompetensi Inti (KI) dan Kompetensi Dasar (KD) dalam Kurikulum 2013. Kemudian dijabarkan menjadi indikator - indikator dan menentukan urutanya.

4) Analisis materi yaitu penyelesaian materi yang sesuai untuk dikembangakan dengan media Augmented Reality. Materi yang dianalisis diutamakan yang memiliki kesukaran dalam penerapan dan pemberian penjelasan dalam pembelajaran. 


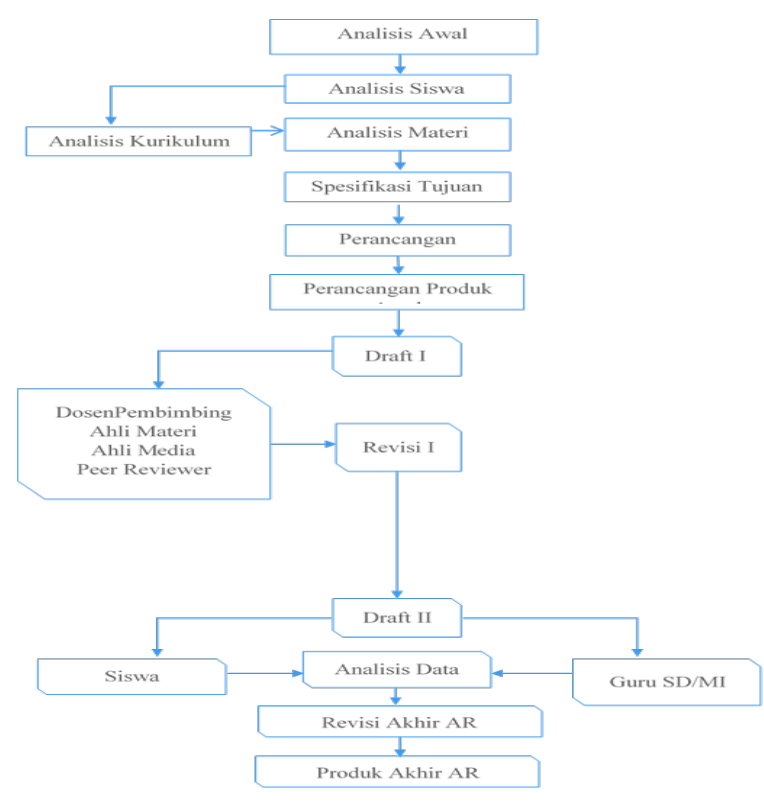

Gambar 1. Gambar pengembangan produk

b. Tahap Design (Perencanaan)

Pada tahap ini, peneliti menyiapkan design objek 3D, design pembuatan marker, dan design membangun aplikasi yang terdiri dari: perancangan Interface (anatarmuka) dan perancangan menu AR. Hasil akhir dari perancangan ini adalah ranacangan produk yang dilanjutkan dengan validitas oleh dosen pembimbing.

c. Tahap Develop (Pengembangan)

Tahap develop bertujuan untuk menilai kelayakan media. Tahap pengambangan terdri dari penilaian oleh reviewer, peer reviewer dan uji coba terbatas.

1) Penilaian

Penilaian dilakukan oleh 1 dosen ahlli materi, 1 dosen ahli media, 1 peer reviewer dan 1 guru kelas. Hasil penelitian oleh reviewer dan peer reviewer menjadi acuan kelayakan 
media pembelajaran Augmented Reality (AR) yang akan dikembangkan.

2) Uji coba terbatas (pada siswa)

Uji coba terbatas dilakukan pada 10 siswa kelas $\mathrm{V}$ MI Wahid Hasyim. Instrumen yang dipergunakan untuk mengumpulkan data uji coba produk berupa lembar angket. Lembar angket ini dipergunakan untuk mendapatkan penilaian atau respon dari siswa meliputi aspek minat belajar, aspek kemudahan pemahaman, aspek tampilan, dan aspek keterlaksanaan. Selanjutnya dilakukan evaluasi menggunakan bentuk uraian non objektif untuk mengetahui pemahaman siswa mengenai materi daur air menggunakan media pembelajaran AR sebagai salah satu alat ukur respon keberhasilan siswa.

\section{Media Pembelajaran}

Binanto menjelaskan secara umum media pembelajaran adalah alat bantu dalam proses belajar mengajar. Berbagai alat yang dapat dipergunakan untuk merangsang pikiran, perhatian, perasaan, dan kemampuan atau ketrampilan pembelajaran tersebut sehingga mampu mendorong terjadinya proses belajar atau kegiatan pembelajaran. Batasan dari media pembelajaran ini cukup luas dan mendalam dengan mencakup pengertian sumber, manusia dan lingkungan serta metode yang dimanfaatkan dari tujuan pembelajaran atau pelatihan tersebut (Saputro, R.E. dan Surya, D.I., 2015:156).

Fungsi media pembelajaran dalam proses pembelajaran adalah sebagai media penyampai informasi. Pemakaian media pembelajaran dalam proses pembelajaran dapat meningkatkan keinginan dan minat anak dalam belajar. Selain membangkitkan minat dan keinginan anak media pembelajan juga membantu proses penyajian materi dan pemahaman anak terkait materi. Empat fungsi media pembelajaran terutama media visual menurut Levie dan Lentz adalah (Azhar, 2013:10): 
a. Fungsi Atensi : Media pembelajaran memiliki fungsi sebagai inti yang mampu menarik dan mengarahkan perhatian siswa untuk berkonsentrasi pada isi pelajaran yang berkaitan dengan makna visual yang ditampilkan atau menyertai teks materi pelajaran. Sering kita tahu bahwa siswa tidak fokus terhadap pembelajaran yang dilakukan, namun setelah menggunakan media pembelajaran kemudian siswa tersebut dapat lebih diarahkan untuk memperhatikan media pembelajaran yang digunakan.

b. Fungsi Afektif: Dapat dilihat dari perilaku siswa ketika belajar teks yang disertai gambar. Media pembelajaran visual mampu menggugah emosi dan sikap siswa, siswa mampu menganalisis dan menanggapi dengan perbuatan terhadap fenomena yang ditampilkan. Media pembelajaran mampu membuat siswa aktif, bahkan siswa mampu mempelajari dan mempraktikan penggunaan media pembelajaran yang digunakan.

c. Fungsi Kognitif: Media pembelajaran visual yang berisi lambang-lambang visual atau gambar dapat memperlancar pencapaian tujuan untuk memahami dan mengingat informasi atau pesan yang terkandung pada apa yang ditampilkan.

d. Fungsi Kompensatoris: Media visual memberi konteks untuk memahami teks mampu membantu siswa yang lemah dalam membaca untuk mengorganisasikan informasi dalam teks dan mengingatnya kembali. Media pembelajaran bisa mengakomodasi peserta didik yang lemah dan lambat menerima dan mempelajari pelajaran yang disajikan tanpa menggunakan media.

\section{Augmented Reality (AR)}

Augmented Reality adalah konsep penggabungan dunia virtual ke dalam dunia nyata. Penciptaan dunia virtual dilakukan untuk membangkitkan persepsi pengguna dalam memahami informasi dari objek yang dikenali (Saurina Nia, 2016:97). Berdasarkan penjelasan 
tersebut maka fungsi dari Augmented Reality (AR) adalah Teknologi yang cocok untuk visualisasi informasi secara intensif. Pemanfaatan Augmented Reality (AR) dapat juga mengungkapkan potensi visualisasi yang hilang di ruang actual, memberikan visualisasi realtime, kapanpun dan dimanapun, serta mengintegrasi emosi virtual penggunanya seperti pengalaman di ruang nyata.

Penerapan Augmented Reality (AR) meningkatkan pengalaman atas kolaborasi ruang nyata dan semu sebagai kontribusi untuk pendidikan. Melalu daur air digital, Augmented Reality (AR) meningkatkan proses pembelajaran dan memfasilitasi pemahaman penggunanya tentang konteks objek alam dan menghubungkan mereka ke tiap detail fisik gejala alam dan siklus yang mendukung, terutama apresiasi rincian sistem daur air dari awal sampai terjadinya hujan. Maka dari itu media pembelajaran AR memiliki keunggulan - keunggulan berdasarkan penelitian terdahulu terutama untuk pembelajaran IPA, sebagai berikut:

a. Media AR mampu menghadirkan ilustrasi materi pembelajaran tiga dimensi sehingga visualisasi menjadi lebih spesifik (Vitalocca, D. dan Mardiana, 2017, 170).

b. Siswa mempunyai pemahaman materi yang lebih beragam dan tervisualisasi (Vitalocca, D. dan Mardiana, 2017, 170).

c. Teknologi AR dapat digunakan oleh guru sebagai alat bantu pengajaran di kelas dan dapat membantu siswa lebih memahami pelajaran IPA (Sari, W.S., Dewi, I.N. dan Setiawan, A., 2012:29).

d. Penyampaian informasi dalam pembelajaran lebih jelas karena dapat menggabungkan dunia virtual dan dunia nyata (Sartika, Y., dkk., 2016:895). Sehingga mata pelajaran IPA yang notabennya gejala alam yang sulit diamati menjadi mudah untuk di pahami dengan adanya visualisasi yang mendekati nyata.

\section{Vuforia}

Vuforia adalah Augmented Reality Software Development Kit (SDK) untuk perangkat mobile yang mampu pembuatan aplikasi 
Augmented Reality, yang digunakan teknologi Computer untuk mengenali dan melacak gambar planar (Gambar Target) dan objek 3D sederhana, seperti kotak, secara real-time. Kemampuan citra ini memungkinkan pengembang untuk posisi dan orientasi obyek virtual, seperti model 3D dan media yang lain, dalam kaitannya dengan gambar dunia nyata saat dilihat melalui kamera dari perangkat mobile. Objek virtual kemudian melacak posisi dan orientasi dari gambar secara real-time sehingga perspektif pengguna pada objek sesuai dengan perspektif mereka pada target gambar, kemudian tampak bahwa objek virtual adalah bagian dari adegan dunia nyata (Dedynggego, Mohammad dan Affan, M., 2015:50).

\section{Marker}

Marker merupakan real enviroment berbentuk objek nyata yang mampu menghasilkan virtual reality, marker ini digunakan sebagai tempat augmented reality muncul, berikut ini beberapa jenis marker yang digunakan pada aplikasi augmented reality (Dedynggego, Mohammad dan Affan, M., 2015:49).

a. Quick Response (QR) Kode dua dimensi yang merupakan bagian dari banyak kotak yang diatur dalam pola persegi, Biasanya QR ini berwarna hitam dan putih, kode QR diciptakan di Jepang pada awal 1990-an dan dipergunakan sebagai alat pelacak berbagai bagian dalam manufaktur kendaraan. Beriring perkembangan zaman $\mathrm{QR}$ kemudian dipergunakan untuk link cepat ke website, dial cepat untuk nomor telepon, bahkan dengan cepat mengirim pesan SMS seperti pada gambar 2. QR (quick response) Code.

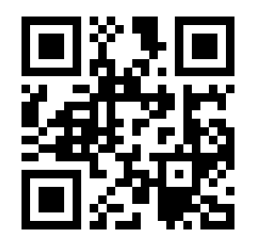

Gambar 2. QR (quick response) Code 
b. Fiducial Marker adalah bentuk yang sering dipergunakan oleh teknologi AR karena marker ini mampu melacak benda-benda di virtual reality tersebut. kotak hitam dan putih dipergunakan untuk titik referensi atau memberikan skala dan orientasi ke aplikasi. Bila penanda tersebut dideteksi dan dikenali maka augmented reality akan keluar dari marker ini seperti pada gambar 3. fiducial marker.

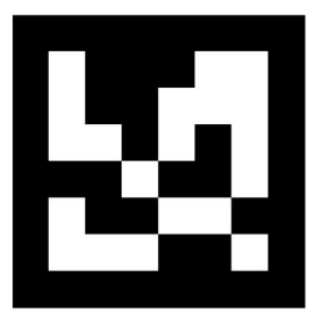

Gambar 3. Fiducial Marker

c. Markerless Marker berfungsi seperti fiducial marker namun bentuk markerless marker tidak mengharuskan penanda berwarna kotak hitam putih, markerless ini berbentuknya bisa bervariasi sesuai gambar yang diinginkan dan bahkan memiliki banyak warna seperti pada gambar 4 . markerless marker.

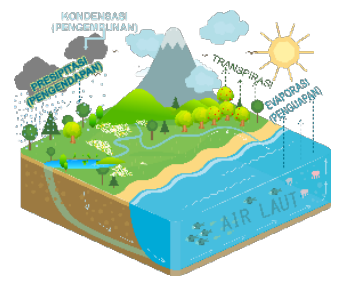

Gambar 4. Markeless Marker

Berdasarkan penjelasan diatas marker yang dibuat untuk media pembelajaran AR adalah Markeless Marker, sehingga marker yang diterapkan menarik dan berfungsi sebagai informasi pengetahuan terhadap materi yang disampaikan. 


\section{3ds Max}

3D Max atau 3D Studio Max merupakan salah satu software yang sering digunakan oleh para pengembang produk untuk merancang dan membuat animasi atau pemodelan dalam bentuk 3 dimensi. Aplikasi ini dirilis oleh salah satu perusahaan autodesk media dan intertainment yang pada mulanya dikenal sebagai discrett dan kinetix. 3ds max adalah salah satu dari sekian banyak aplikasi modeling untuk merancang dan membuat model 3D dan paling banyak digunakan oleh perancang diseluruh dunia. Aplikasi ini memudahkan user untuk mengeksplore kemampuan dan daya imajinasi kita untuk menciptakan atau menghasilkan suatu hasil karya berbentuk 3D baik itu berupa objek benda sampai objek berbentuk karakter yang unik (Suhendar, A. dan Fernando, A., 2016:31).

3Ds Max yang digunakan pada pengembangan ini yaitu 3Ds Max 2014, dimana fungsi dari 3Ds Max dalam penelitian ini adalah sebagai alat pembuat siklus air 3 dimensi yang kemudian disimpan pada jenis file ".FBX" yang kemudian dilanjutkan dalam pengerjaannya menggunakan unity untuk menghasilkan media yang sedang dikembangkan oleh peneliti.

\section{Hasil Penelitian}

Hasil penelitian ini berupa media pembelajaran yang dirancang khusus untuk diapikasikan pada handphone. Media pembelajaran ini lebih difokuskan untuk belajar mandiri siswa. Hasil dari pengembangan media dikemas dalam bentuk master aplikasi yang memiliki extensi file ".APK" (application pakage) yang selanjutnya digunakan untuk menginstal aplikasi pada handphone android. Aplikasi media pembelajaran AR disajikan dalam beberapa menu pilihan antara lain: menu AR camera dan menu AR video. Masing masing menu memiliki fungsi tersendiri untuk memberi kemudahan siswa belajar secara mandiri. Berdasarkan hasil penelitian berikut adalah hasil dari tanggapan guru dan siswa. 


\section{a. Guru Kelas}

Guru kelas menilai media AR dari aspek kualitas tampilan, aspek rekayasa perangkat lunak, aspek kurikulum, aspek penyajian materi, aspek keterlaksanaan, aspek evaluasi, aspek kebahasaan. Berikut hasil data penilaian media AR oleh Guru kelas pada table 1.

Tabel 1. Penilaian Media AR oleh Guru Kelas

\begin{tabular}{|c|c|c|c|c|c|c|}
\hline $\mathrm{NO}$ & Aspek Kriteria & Indikator & $\begin{array}{l}\text { Skor } \\
\text { Max }\end{array}$ & $\begin{array}{l}\text { Skor } \\
\text { Rata- } \\
\text { Rata }\end{array}$ & $\begin{array}{c}\text { Persentase } \\
\text { ideal (\%) }\end{array}$ & kualiatas \\
\hline 1 & $\begin{array}{l}\text { Aspek Kualitas } \\
\text { Tampilan }\end{array}$ & $1,2,3,4,5$ & 25 & 4.2 & $84 \%$ & SB \\
\hline 2 & $\begin{array}{l}\text { Aspek Rekayasa } \\
\text { Perangkat } \\
\text { Lunak }\end{array}$ & $6,7,8$ & 15 & 4.7 & $94 \%$ & SB \\
\hline 3 & $\begin{array}{l}\text { Aspek } \\
\text { Kurikulum }\end{array}$ & 9,10 & 10 & 4 & $80 \%$ & B \\
\hline 4 & $\begin{array}{l}\text { Aspek } \\
\text { Penyajian } \\
\text { Materi }\end{array}$ & $11,12,13$ & 15 & 4 & $80 \%$ & B \\
\hline 5 & $\begin{array}{l}\text { Aspek } \\
\text { Keterlaksanaan }\end{array}$ & 14,15 & 10 & 4 & $80 \%$ & B \\
\hline 6 & Aspek Evaluasi & 16,17 & 10 & 4 & $80 \%$ & B \\
\hline \multirow[t]{3}{*}{7} & $\begin{array}{l}\text { Aspek } \\
\text { Kebahasaan }\end{array}$ & 18,19 & 10 & 4 & $80 \%$ & B \\
\hline & Jumalah & & & 28.9 & & \\
\hline & Total Pers & entase Idea & & & $82.57 \%$ & SB \\
\hline
\end{tabular}




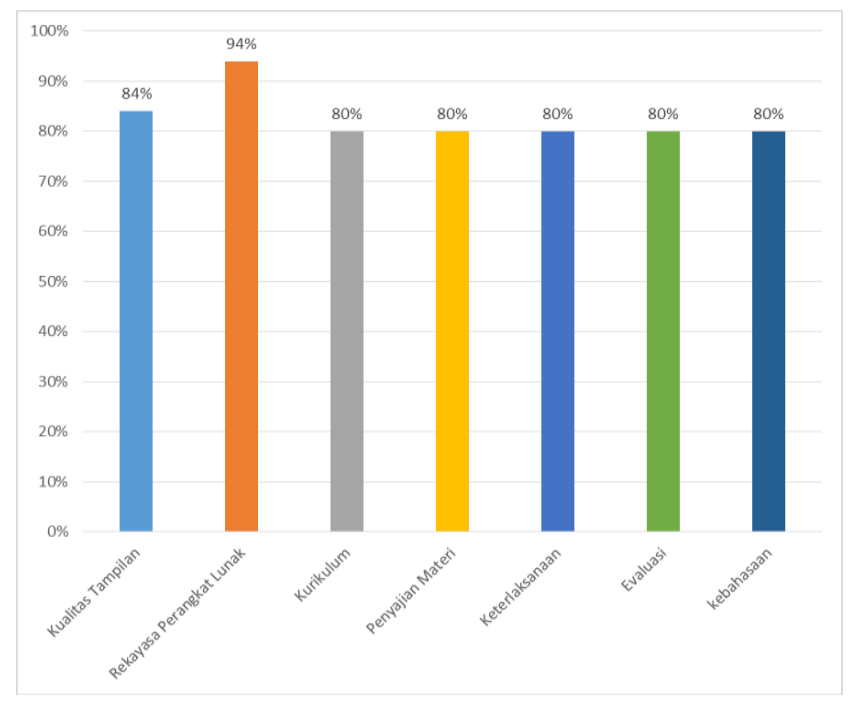

Gambar 5. Grafik hasil penilaian guru kelas

Berdasarkan gambar 5. di atas menunjukkan aspek kualitas tampilan memperoleh persentase $84 \%$, aspek rekayasa perangkat lunak memperoleh persentase $94 \%$, aspek kurikulum memperoleh persentase sebesar $80 \%$, aspek penyajian materi memperoleh persentase sebesar $80 \%$, aspek keterlaksanaan memperoleh persentase sebesar $80 \%$, aspek evaluasi memperoleh persentase sebesar $80 \%$, dan aspek kebahasaan memperoleh persentase sebesar $80 \%$. Penelitian keaseluruhan aspek oleh guru kelas dapat dilihat pada tabel 4.4 dengan skor rata - rata 28.9 dan memperoleh persentase ideal sebesar $82.57 \%$, berdasarkan data tersebut maka tergolong pada karakteristik sangat baik (SB). Adapun tanggapan yang diberikan oleh guru kelas sebagia berikut.

"Sebuah terobosan yang bagus, sangat berguna dan sesuai diterapkan di tingkat SD/MI sebagai media pembelajaran".

Dari tanggapan tersebut maka media pembelajaran AR. mampu memberikan kebutuhan yang diperlukan sebagai alat bantu pembelajaran. Sehinga mampu sebagai salah satu penunjang memudahkan dalam memahami materi.

\section{b. Tanggapan Siswa}

Tanggapan siswa dilakukan dengan melihat respon siswa yang berupa tanggapan siswa terhadap produk media pembelajaran 
AR, siswa diberi kesempatan untuk menilai dan memberikan masukan. Penilaian siswa meliputi beberapa aspek yaitu aspek minat belajar, aspek kemudahan pemahaman, aspek tampilan, aspek keterlaksanaan. Hasil tanggapan secara keseluruhan terhadap media AR yang dilakukan 10 siswa MI Wahid Hasyim kota Yogyakarta disajikan pada tabel 5 sebagai berikut:

Tabel 2. Kualitas Media AR tanggapan 10 siswa kelas V MI Wahid Hasyim

\begin{tabular}{|c|c|c|c|c|c|c|}
\hline $\mathrm{NO}$ & Aspek Kriteria & Indikator & $\begin{array}{l}\text { Skor } \\
\text { Max }\end{array}$ & $\begin{array}{l}\text { Skor } \\
\text { Rata- } \\
\text { Rata }\end{array}$ & $\begin{array}{l}\text { Persentase } \\
\text { ideal (\%) }\end{array}$ & $\begin{array}{c}\text { Kategori } \\
\text { Nilai }\end{array}$ \\
\hline 1 & $\begin{array}{l}\text { Aspek Minat } \\
\text { Belajar }\end{array}$ & $1,2,3$ & 30 & 2.9 & $96.67 \%$ & Positif \\
\hline 2 & $\begin{array}{l}\text { Aspek } \\
\text { Kemudahan } \\
\text { Pemahaman }\end{array}$ & 4,5 & 20 & 1.9 & $95 \%$ & Positif \\
\hline 3 & $\begin{array}{l}\text { Aspek } \\
\text { Tampilan }\end{array}$ & $6,7,8$ & 30 & 3 & $100 \%$ & Positif \\
\hline 4 & $\begin{array}{l}\text { Aspek } \\
\text { Keterlaksanaan }\end{array}$ & 9,10 & 20 & 1.9 & $95 \%$ & Positif \\
\hline & Jumalah & & 100 & 9.7 & & Positif \\
\hline \multicolumn{5}{|c|}{ Total Persentase Ideal } & $97 \%$ & Positif \\
\hline
\end{tabular}

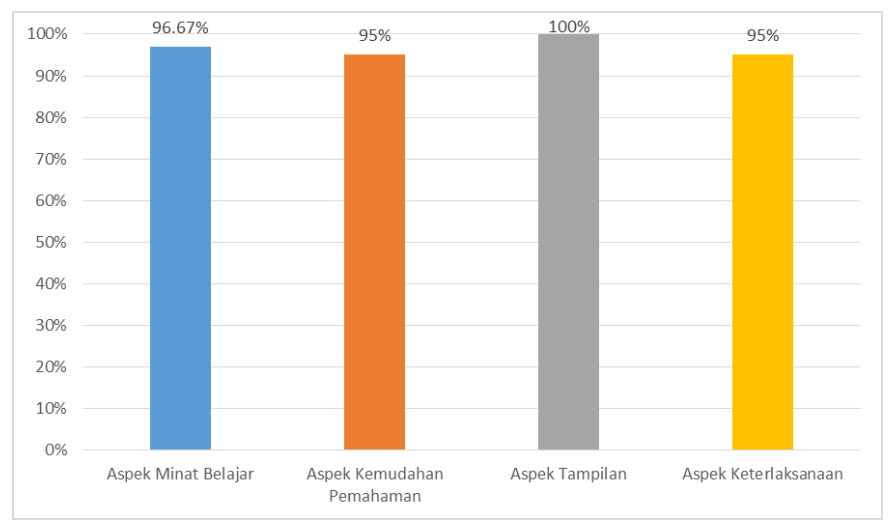

Gambar 6. Grafik hasil tanggapan 10 siswa kelas V MI Wahid Hasyim

Elementary Vol. 7 No. 2 Juli-Desember 2019 
Berdasarkan gambar 6. di atas dapat diketahui persentase setiap aspek yaitu aspek minat belajar sebesar 96.67\%, aspek kemudahan pemahaman sebesar 95\%, aspek tampilan sebesar $100 \%$, aspek keterlaksanaan 95\%. Sehingga kita ketahui hasil tertinggi diperoleh pada aspek tampilan yaitu 100\% dengan kategori Positif dan jika di masukkan pada kategori kelayakan Sangat Bagus (SB) atau Sangat Layak. Kemudian hasil terendah pada aspek kemudahan dan aspek keterlaksanaan yang memiliki persentase sama yaitu 95\% dengan kategori Positif dan jika di masukkan pada kategori kelayakan Sangat Bagus (SB) atau Sangat Layak. Selanjutnya pada tahap ini siswa dievaluasi dengan cara mendiskripsikan dan menggambarkan materi yang telah mereka pelajari melalui media pembelajaran Augmented Reality (AR). Hasil dari evaluasi, siswa mampu mencapai tujuan pembelajaran secara mandiri dengan baik., yaitu jika dikakulasikan dengan angka memperoleh nilai rata - rata 82. Nilai rata -rata tersebut naik $35.8 \%$ dari hasil rata - rata nilai IPA siswa yang sebelumnya.

\section{Simpulan}

Berdasarkan Penelitian pengembangan yang telah dilakukan, dapat diperoleh kesimpulan bahwa media pembelajaran Augmented Reality (AR) berdasarkan respon ataupun penilaian guru dan siswa memiliki persentase $82.57 \%$ dengan respon guru pada kategori sangat baik dan perersentase $97 \%$ pada kategori sangat baik dan memiliki respon positif oleh siswa yang kemudian diperkuat dengan hasil evaluasi dengan nilai rata-rata 82 sehingga nilai siswa pada mata pelajaran IPA mengalami kenaikan $35.8 \%$ yang bisa disimpulkan memiliki respon baik. Berdasarkan hasil perolehan data menunjukkan bahwa media pembelajaran Augmented Reality (AR) materi daur air layak digunakan sebagai sumber belajar siswa kelas V SD/MI. 


\section{DAFTAR PUSTAKA}

Azhar, Media Pembelajaran. Jakarta: Rajawali Press, 2013.

Atmajaya, Dedy, "Implementasi Augmented Reality Untuk Pembelajaran Interaktif," dalam Jurnal Ilmiah ILKOM, Vol. 9, Nomor 2, Agustus 2017. Asnawir, Usman, B., Media Pembelajaran, Jakarta : Ciputat Pers, 2002.

Boud, A. C., Haniff, D. J., et al. 1999. Virtual reality and augmented reality as a training tool for assembly tasks. In Information Visualization, Proceedings. IEEE International Conference on, 1999. doi:10.1109/iv.1999.781532.

Bahar, Y., N., "Aplikasi Teknologi Virtual Realty Bagi Pelestarian Bangunan Arsitektur", dalam Jurnal Desain Konstruksi, Volume 13, No. 2, Desember 2014.

Budiman, A. A., "Aplikasi Mobile Augmented Reality Berbasis Android Sebagai Media Pembelajaran Gigi Berlubang," dalam Jurnal Teknik dan Ilmu Komputer, Vol. 21 No. 06, Jan - Mar 2017.

Dunleavy, M., Dede, D., and Mitchell, R., Affordances and Limitations of Immersive Participatory Augmented Reality Simulations for Teaching and Learning, on Journal of Science Education and Technology, Vol. 18, No. 1, February 2009.

Dedynggego, Mohammad, Affan, M., “Perancangan Media Pembelajaran Interaktif $3 d$ Tata Surya Menggunakan Teknologi Augmented Reality Untuk Siswa Kelas 6 Sekolah Dasar Sangira", dalam jurnal Elektronik Sistem Informasi Dan Komputer, Vol. 1, Nomor 2, Juli - Desember 2015.

Gatot S. Dewa Broto, Riset Kominfo dan UNICEF Mengenai Perilaku Anak dan Remaja Dalam Menggunakan Internet. Dalam www. kominfo.go.id. Diakses tanggal 11 Desember 2017.

Kustandi, C.,Sutjupto, B., Media Pembelajaran Manual dan Digital, Bogor: Ghalia Indonesia, 2013.

Sanou, B., Measuring the Information Society Report 2015 Executive Summary, Switzerland: CH-1211 Geneva Switzerland, 2015.

Saputro, R.E., Surya, D.I., “Pengembangan Media Pembelajaran Mengenal Organ Pencernaan Manusia Menggunakan 
Teknologi Augmented Reality", dalam Jurnal Buana Informatika, Vol. 6, Nomor 2, April 2015.

Sari, W. S., dkk., "Multimedia Presentasi Pembelajaran Berbasis Augmented Reality untuk Pengenalan Pancaindra dalam Mendukung Mata Pelajaran IPA Tingkat Sekolah Dasar," paper dipersentasikan dalam Seminar Nasional Teknologi Informasi $\mathcal{E}$ Komunikasi Terapan 2012 (Semantik 2012), Semarang, 23 Juni 2012. Saurina, Nia, "Pengembangan Media Pembelajaran Untuk Anak Usia Dini Menggunakan Augmented Reality," dalam Jurnal IPTEK, Fakultas Teknik, Vol. 20, Nomor 1, Mei 2016.

Sari, W.S., Dewi, I.N., Setiawan, A., "Multimedia Presentasi Pembelajaran Berbasis Augmented Reality untuk Pengenalan Pancaindra dalam Mendukung Mata Pelajaran IPA Tingkat Sekolah Dasar", dalam Seminar Nasional Teknologi Informasi \& Komunikasi Terapan 2012, Juni 2012.

Sartika, Y., dkk., "Aplikasi Pembelajaran Tata Surya untuk IPA Kelas 6 Sekolah Dasar Menggunakan Augmented Reality Berbasis Android", dalam e-Proceeding of Applied Science, Vol. 2, Nomor 3, Desember 2016.

Suhendar, A., Fernando, A., " Aplikasi Virtual tour Berbasis Multimedia Interaktif Menggunakan Autodesk 3Ds Max", dalam Jurnal ProTekInfo, Vol. 3, Nomor 1, September 2016.

Sugiyono, Metode Penelitian Pendidikan (Pendekatan Kuantitatif, Kualitatif dan RED), Bandung: Alfabeta, 2009.

Tim Puslitjaknov, Metode Penelitian dan Pengembangan, Jakarta: Pusat Penelitian Kebijakan dan Inovasi Pendidikan Badan Penelitian dan Pengembangan Depdiknas, 2008.

Trianto, Mendisain Model Pembelajaran Inovasi Progesif "Konsep, Landasan, dan Implementasinya pada Kurikulum Tingkat Satuan Pendidikan (KTSP)", Jakarta: Kencana Prenada Media Group, 2013.

Vitalocca, D., Mardiana, "Pengaruh Implementasi Augmented Reality (Ar) Sebagai Media Pembelajaran Terhadap Hasil Belajar Siswa SD Pada Mata Pelajaran IPA", dalam Seminar Nasional Pendidikan Vokasi, Fakultas Teknik Universitas Negeri Makasar, 9 September 2017. 